IZA DP No. 5108

Intergenerational Transfer of Human Capital under Post-War Distress: The Displaced and the Roma in the Former Yugoslavia

Martin Kahanec

Mutlu Yuksel

August 2010 


\title{
Intergenerational Transfer of Human Capital under Post-War Distress: The Displaced and the Roma in the Former Yugoslavia
}

\author{
Martin Kahanec \\ Central European University \\ and IZA \\ Mutlu Yuksel \\ Dalhousie University \\ and IZA
}

Discussion Paper No. 5108

August 2010

IZA
P.O. Box 7240
53072 Bonn
Germany

Phone: +49-228-3894-0

Fax: +49-228-3894-180

E-mail: iza@iza.org

Any opinions expressed here are those of the author(s) and not those of IZA. Research published in this series may include views on policy, but the institute itself takes no institutional policy positions.

The Institute for the Study of Labor (IZA) in Bonn is a local and virtual international research center and a place of communication between science, politics and business. IZA is an independent nonprofit organization supported by Deutsche Post Foundation. The center is associated with the University of Bonn and offers a stimulating research environment through its international network, workshops and conferences, data service, project support, research visits and doctoral program. IZA engages in (i) original and internationally competitive research in all fields of labor economics, (ii) development of policy concepts, and (iii) dissemination of research results and concepts to the interested public.

IZA Discussion Papers often represent preliminary work and are circulated to encourage discussion. Citation of such a paper should account for its provisional character. A revised version may be available directly from the author. 


\section{ABSTRACT}

\section{Intergenerational Transfer of Human Capital under Post-War Distress: The Displaced and the Roma in the Former Yugoslavia*}

In this chapter, we investigate the effects of vulnerability on income and employment in Bosnia and Herzegovina, Croatia, Montenegro and Serbia using a unique 2004 UNDP dataset. Treating the collapse of the former Yugoslavia as a natural experiment, we compare three groups that have been differently affected by the wars and post-war distress: the majority as the benchmark, the ex-ante and ex-post vulnerable Roma people, and the exante equal but ex-post vulnerable refugees and internally displaced people (RIDPs). Our findings reveal significant negative effects of vulnerability on income and employment. RIDPs seem to be about as negatively affected as Roma across the four states, which indicate that vulnerability inflicted by relatively recent displacement may have similar effects as vulnerability rooted deep in the past. When we look at education as one of the key determinants of socio-economic outcomes, both groups exhibit similarly substandard educational outcomes of children and significant inertia in intergenerational transfer of human capital. Our findings highlight the need for policies that not only tackle vulnerability as such, but address the spillover effects of current vulnerability on future educational attainment.

JEL Classification: $\quad$ I21, I12, J24, N34

Keywords: vulnerability, labor market, education, Roma, refugees, internally displaced people, discrimination, integration

Corresponding author:

Mutlu Yuksel

Department of Economics

Dalhousie University

6214 University Avenue

Halifax, NS, B3H $3 J 5$

Canada

E-mail:mutlu@dal.ca

\footnotetext{
* We are especially grateful to Mevlude Akbulut-Yuksel for very useful comments and discussions. The authors bear the sole responsibility for any errors that may remain.
} 


\section{Introduction}

It has become customary in the literature to look at the roles that ethnicity and immigrant origin may play for socio-economic outcomes in contexts characterized by a static partition of the studied population by ethnicity or immigrant origin. Vulnerability in terms of inclusion into social and economic relationships and outcomes is then ascribed to these static measures. Zimmermann and Constant (2008) propose a two dimensional measure of ethnicity whereby the strength of the attachment to the host and own cultures is measured and shown to affect socioeconomic outcomes.

In some situations, however, ethnicity remains constant but the changing context interacts with ethnicity and engenders vulnerability of some ethnic groups. One such example is the case of former Yugoslavia, where the violent conflicts of the 1990s gave rise to new boundaries and displaced people along ethnic lines. Internally displaced persons (IDPs) "Persons or groups of persons who have been forced or obliged to flee or to leave their homes or places of habitual residence, in particular as a result of or in order to avoid the effects of armed conflict, situations of generalized violence, violations of human rights or natural or human-made disasters, and who have not crossed an internationally recognized state border” exemplify such a situation. ${ }^{1}$ Examples include Serbs displaced from Kosovo to Serbia during or shortly after the NATO bombing of Kosovo in 1999; or Muslim Bosnians displaced from Serb-dominated parts of Bosnia and Herzegovina to Bosnia as a consequence of the Bosnian War (1992-1995).

A remarkable peculiarity of displacement in former Yugoslavia is that in most cases displacement entailed a changing status from being a minority in the given settlement (e.g. Muslim Bosnian in a predominantly Serb village in Bosnia and Herzegovina) to being a member

\footnotetext{
${ }^{1}$ UN High Commissioner for Refugees, 1998.
} 
of ethnic majority (e.g. Muslim Bosnian in Bosnia). This applies to the displaced Serbs as well, who were dominant in Yugoslavia, but were displaced from non-Serb settlements to those dominated by Serbs. Another specific feature of the context of former Yugoslavia is that several groups that were a minority before the 1990s have become a majority group in the newly emerged states (e.g. Kosovars in Kosovo). The context of former Yugoslavia thus enables one to study socio-economic outcomes of people that were ex-ante fairly integrated and equal, but put in a vulnerable position by the armed conflicts of the 1990s that resulted in their displacement and ex-post vulnerability that does not match the traditional ethnic minority-majority dichotomy.

In this chapter we evaluate the effect of vulnerability on income and employment in the context of former Yugoslavia. We study the effects of vulnerability for two groups that shared the social, political, and economic developments and the distress caused by the armed conflicts, yet their experience differed in their ex-ante and ex-post vulnerability: The RIDPs who were put in a vulnerable position by exogenous events - the Yugoslav wars and the Roma who were in a vulnerable position regardless of the wars. Those who were neither displaced nor members of the Roma ethnic minority can serve as a natural control group. As educational attainment is one of the key determinants of socio-economic outcomes, we then study the educational attainment of children and intergenerational transfer of human capital across the three studied groups. This approach enables us to elucidate the long-run effects of vulnerability on socio-economic outcomes.

The possibility to benchmark RIDPs' outcomes, besides the usual control group of those who were not affected or vulnerable, to those of the people who were vulnerable ex-ante as well as ex-post makes the former Yugoslav context particularly interesting for the study of vulnerability. In fact, being tied to the fall of the Berlin War that marked the end of the bipolar 
world order that weakened the communist federal regime in SFRY and unleashed the separatist factions in turn, these armed conflicts can in fact be interpreted in the present study as a natural experiment. This enables us under certain conditions to interpret the effects of vulnerability on income and employment outcomes as causal.

In the next section we review the literature on the topics studied. We then discuss the context of former Yugoslavia and the fates of IDPs and Roma in particular. The following section introduces and describes the data. We then develop an estimation strategy and present the results. Finally, we conclude and discuss some policy implications.

\section{Literature Review}

Extensive literature looks at association between armed conflicts and country’s socioeconomic performance from a macroeconomic perspective. This strand of the literature mainly finds that war impacts are limited to the destruction of physical capital, in line with the predictions of the neoclassical economic growth model, which suggests rapid catch-up growth postwar. Among others, using the extensive U.S. bombing campaign in Vietnam as a quasi experiment, Miguel and Roland (2005) show that U.S. bombing did not have had long lasting impacts on poverty rates, consumption levels, infrastructure, literacy and population density 25 years after the war in Vietnam. Studies that focus on United States bombing during WWIIincluding in Japan (Davis and Weinstein 2002), Germany (Brakman et al 2004) - also find few if any persistent impacts of the bombing on local population or economic performance. Along these lines, Organski and Kugler $(1977,1980)$ provide similar evidence on war devastation mainly for European countries suggesting that for both capitalist and socialist economies, the economic effects of the two world wars tended to dissipate after only 15-20 years. 
Due to data constraints however, only a handful of studies has attempted to provide micro-level evidence on the cost of armed conflicts on civilians' outcomes. Using plausibly exogenous city-by-cohort variation in the intensity of WWII destruction in Germany as a natural experiment, Akbulut-Yuksel (2009) shows that wartime destruction had a substantial negative effect on long-term human capital formation, health and labor market outcomes of Germans who were at school-age during WWII. Angrist and Kugler (2008) show that an exogenous upsurge in conflict activities arising from increase in coca prices and cultivation in Colombia has a negative effect on teenager boys' school enrollment. Shemyakina (2006) examines the effects of civil conflict in Tajikistan and finds that girls residing in conflict areas are less likely to complete secondary school education; however, the civil conflict had little, or no, effect on educational attainment of boys. Similarly, using WWII as an instrumental variable to estimate the causal effect of education on earnings, Ichino and Winter-Ebmer (2004) find that individuals who were 10 years old during or immediately after WWII acquire less education and earned significantly less in adulthood compared to other cohorts within Germany and Austria as well as to individuals of the same cohort born in non-war countries (namely, Switzerland and Sweden).

This study closely relates to literature looking the labor market impacts of displacement. Using the 15 years of civil conflict in Colombia as a natural experiment, Calderón-Mejía and Ibanez (2009) study the impact of forced migration on the labor market outcomes. To address the endogeneity in the location decision, they use an interaction of the number of massacres at the origin and the distance to the state capital as an instrumental-variable for these immigrants final destination. They find that the labor supply shock induced by the displaced people has negative impacts on wages and employment opportunities of all workers, but these adverse labor market impacts are particularly large for low skill workers. Kondylis (2008) provides similar evidence 
from the civil conflict in Bosnia and Herzegovina. Using the level of violence in the pre-war residence as an instrument for individual's displacement, she finds that there is a positive selection into displacement. However, she shows that displaced Bosnians are less likely to be in work, particularly women, even though they assimilate into the labor market over time. She suggests that the high levels of informality are likely to contribute to the negative effect of displacement. However, the inactivity of Bosnian women after displacement also leaves room for channels such as cultural and sociological factors that play an important role in intra-household allocations.

This chapter also contributes to literature looking at Roma and their socio-economic outcomes. Using data from the UNDP/ILO survey conducted in Bulgaria, the Czech Republic, Hungary, Romania and Slovakia in 2001, Milcher and Zigová (2005) analyze the educational attainment of Roma people and to what extent their human capital is rewarded in the labor market. They test whether the insufficient education is a mediator for their weak attachment to the labor market and high poverty among Roma. First, they find that Roma people are more likely to reside in regions with lower economic performance and school enrollment rates. Second, they show that the likelihood of obtaining a regular wage job increases and the probability of being passive beneficial decreases substantially if one household member has higher education. Moreover, they find that the propensity to have occasional wage income is similar across different education categories and education has a marginal, negative impact on the probability of households living on loans. Although the education serves as a way out of poverty trap for Roma people, they concluded that education is more important for Roma residing in less developed economies in Central and Eastern Europe. 
O’Higgins and Ivanov (2006) revisit the same questions using two surveys compiled in 2002 and 2004. Similar to Milcher and Zigová (2005), they find that the lack of formal education explains the considerable part of the high unemployment among Roma. However, they also find that discrimination against Roma in the labor market has an important role for their weaker labor market attachment. Thus, due to the statistical and taste-base discrimination in the labor market, majority of Roma people work in informal sector in low-quality jobs. The authors argue that policy makers should devise labor market programs that are likely to generate opportunities for autonomous income rather than temporary employment programs to improve the labor market outcomes of Roma people.

Milcher (2006) provides further evidence on the well-being and vulnerability of Roma people. Using micro-level data on Roma, refugees, internally displaced persons (IDPs) and the majority living in close proximity to the Roma, she first shows that income and expenditure are highly correlated with individual's educational attainment, labor market outcomes, and access to secure housing and health care. However, the difference between poor and non-poor households is less pronounced in Roma sample relative to refugees and internally displaced sample. In other words, she finds that regardless of education or other individual characteristics, the probability of being poor is substantially higher among Roma people or, to a lesser extent, among refugee or IDP compared to the majority population.

\section{Background on Internally Displaced People and Roma Population in Europe}

One of the venerable groups we analyze in this study is internally displaced people. In the UN report (2006), internally displaced person is defined as "Persons or groups of persons who have been forced or obliged to flee or to leave their homes or places of habitual residence, in 
particular as a result of or in order to avoid the effects of armed conflict, situations of generalized violence, violations of human rights or natural or human-made disasters, and who have not crossed an internationally recognized state border". According to the Internal Displacement Monitoring Centre (IDMC) in 2005, there were 24 million internally displaced people in 51 countries worldwide. In contrast to other vulnerable groups across the globe, displaced people are not necessarily vulnerable before their displacement per se (UN, 2006). However, the conflicts and the consequent displacements mostly cost them their wealth, homes, jobs and networks. In many cases, they have limited ability to transfer their human capital to their new destinations and have hardship in entering the local labor market in their new homes.

In this study, we mainly focus on individuals and families in the Central and Eastern Europe who were displaced during the last two decades. Due to the outbreaks of series of civil conflicts and political turmoil in Socialist Federal Republic of Yugoslavia during 1990s, thousands of families were forced to leave their homes and communities without the institutional and organizational infrastructure to accommodate such displacement. In general, inter-ethnic relations in pre-war Socialist Federal Republic of Yugoslavia were cordial, as Tito managed to enforce a strict policy of "brotherhood and unity" by suppressing ethno-nationalism among the various "nationalities" or "ethnicities". However, shortly after the fall of the Berlin Wall, the communist federal regime in Socialist Federal Republic of Yugoslavia weakened mounting tensions between Federalist (Serbs, Yugoslavs) and Separatist factions (Croats, Slovenes). Subsequently, Croatia, Macedonia and Slovenia declared independence in 1991 and Yugoslavia began to dissolve. Following these events, civil war broke out in Bosnia (1992-1995) between the pro-independence Bosniak-Croat coalition and the Serbs who boycotted the referendum for independence (Swee, 2009). At the same time, the Croatian War of Independence (1991-1995) 
broke out between the Croatian army and the Serbia-controlled Yugoslav People's Army (JNA) and the local ethnic Serbs in Croatia, when the latter announced their secession from Croatia. As a result, the Serb forces in Bosnia and Croatia carried out waves of aggression that marked the earliest events of the Bosnian War and Croatian War of Independence, killing and displacing thousands of Bosnians and Croats (Vulliamy, 1994).

In August 1995, the North Atlantic Treaty Organization conducted sustained air strikes against the Serb strongholds, thus internationalizing the conflict in its final stages (Owen, 1997a; Owen, 1997b). Subsequently, Serbs, Bosnian and Croats signed the Dayton Peace Agreement in December 1995, concluding the Europe's deadliest conflict since WWII. The agreement partitioned Bosnia by an Inter-Entity Boundary Line (IEBL) into two ethnically-divided entities - the Bosniak-Croat Federation of Bosnia and Herzegovina (FBiH) and the Serb Republika Srpska (RS).

Overall, the human cost of the armed conflict was tremendous. Reports by the International Criminal Tribunal for the former Yugoslavia (ICTY) estimate that 102,000 people were declared missing or dead. According to 1999 data, the conflict in Bosnia and Herzegovina caused 2.2 million people to be displaced from their homes, which is half of the total population of Bosnia and Herzegovina estimated in the 1991 Census. Between 1996 and 2004, over 1 million of the displaced return back to their pre-war residences both from locations in Bosnia and Herzegovina, from other Yugoslav successor states, and from further abroad. Even though refugee returns have continued since then, it seems that close to a million Bosnians retain some form of displaced status (UN, 2006).

The second source of major displacements in the territory of former-Yugoslavia was the armed conflict in Kosovo. During the Socialist Federal Republic of Yugoslavia, Kosovo was 
given an autonomous status within the Republic of Serbia since the majority of the population in Kosovo was Albanian. However, Kosovo declared independence with the dissolution of Socialist Federal Republic of Yugoslavia, which initiated the years of conflict between Yugoslav government and Kosovo Albanian rebel guerillas (and the near conflagration in Macedonia in 2001). The conflict was resolved after NATO attacked Yugoslavia, and Yugoslav troops were withdrawn from Kosovo. Nevertheless, like the aforementioned conflicts in Bosnia and Croatia, war in Kosovo caused a massive displacement of population in Kosovo which is estimated to be close to 1 million people.

Another vulnerable group we examine in this study is Roma people who have been historically subjected to persecution and discrimination (Fraser, 1992). Estimates suggest that there are approximately 5-10 million Roma people worldwide, majority of them residing in the Central and Eastern Europe. Roma is one of the most vulnerable groups in Europe with very low labor force participation, extremely high unemployment (often reaching 50-80 percent). Even when Roma people are employed, they primarily work in the informal sector in unsecured jobs, especially in Southeastern Europe. A lack of formal education, poor health and discrimination has been put forward as some of the potential reasons for the under-representation of Roma in the formal sector. For instance, the UN study in 2006 reports that two out of three Roma (compared with one in seven in majority communities) do not complete primary school, and two out of five (compared to 1 in 20 in majority communities) do not attend primary school. The figures are even more striking when we focus only on Roma women. Estimates in the UN report show that three quarters of Roma women do not complete primary education (compared with one in five women from majority communities) and almost a third is illiterate (compared with 1 in 20 women from majority communities). 
The economic and social vulnerability of Roma population seem to prevail over generations. Like their parents, Roma children have lower educational attainment, spend less time at school and are more likely to be illiterate. For instance, 38\% of Roma children do not complete elementary school, compared to only $4 \%$ for children from majority households. On the other hand, only a small fraction of Roma children with elementary education stay on at school to complete either primary or secondary education.

\section{Data and Descriptive Statistics}

In this chapter, our results are based on the UNDP's Vulnerable Groups Survey, conducted in Albania, Bosnia and Herzegovina, Bulgaria, Croatia, Macedonia, Montenegro, Romania, Serbia and Kosovo in 2004. UNDP conducted a comprehensive survey on all the households in Roma settlements and areas with large fraction of Roma population, RIDPs, and residents of majority communities living in close proximity to these two vulnerable groups. This survey provides a wide range of information on individual and household characteristics as well as detailed information on community environment, labor market and discrimination. In the empirical analysis, we mainly use information collected in Croatia, Bosnia and Herzegovina, Montenegro, and Serbia from this survey as displaced people in the sample are residing only in these countries.

In UNDP data, the areas with Roma enclaves were determined using countries' census data. UNDP survey was conducted in areas where percentage of Roma was equal to or higher than the nationwide percentage of Roma obtained from census data. Likewise, communities with large share of refugees/displaced people(RIDPs, thereafter) were defined following the similar methodology. However, in order to construct the national averages for RIDPs, official registries 
and data provided by relevant institutions dealing with displaced populations were used for the sampling design instead of census data. In addition, UNDP data provides detailed information on majority population defined as "non-Roma, non-displaced" that is living in close proximity to these two vulnerable groups. The control groups' samples were constructed using similar approach as for the two vulnerable groups. For Roma sample, majority population interviewed is representative samples of non-Roma communities living in settlements with Roma communities of 'average and above' size. Similarly, the control group for displaced sample is non-displaced populations living in close proximity. In this respect, our data is representative within communities with larger share of Roma and RIDPs. Thus, it is worth noting that the status of majority samples could be worse than national averages as these samples are representative of communities living in close proximity to the two vulnerable samples. However, these control groups still provide the 'benchmark' needed for evaluation of Roma and displaced persons' poverty and vulnerability since they live in the same community and face with similar hurdles.

The strengths of this data are multifold. First of all, it is an unique data that allows us to analyze the majority, the ex-ante and ex-post vulnerable Roma people, and the ex ante equal but ex-post vulnerable internally displaced people (IDPs) within the same dataset. Most of the previous studies were able to study only one of these aforementioned vulnerable groups in Europe; however analyzing Roma and internally displaced people together may help us understand the hurdles these groups encounter in labor market and human capital formation and devise policies to improve the next generations' economic status and wellbeing. Second, it provides similar information on Roma and RIDPs for all ex-Yugoslavian countries, which allows us to compare experiences of Roma and RIDPs across different countries. 
Table 1 presents the characteristics of household heads for majority population, Roma and RIDPs in ex-Yugoslavian countries, respectively. Hence, mostly household heads provide general information about the household and each person residing in the household in the survey, they entail detailed analysis. Table 1 points to substantial differences in characteristics of household heads between majority population and two vulnerable groups. For example, in Bosnia and Herzegovina, Roma household heads are younger, have larger household size, lower employment probabilities, labor market income and household income as well as educational attainment relative to both majority and RIDPs. On the other hand, household heads in RIDP households are only slightly different from majority household heads in terms of age, marital status, household size, employment probability and education. Similar to majority, 50\% of RIDP household heads have secondary education and their average years of schooling are approximately 10 years. However, Table 1 also shows that their high levels of educational attainment are not rewarded in the labor market of host communities. It seems that RIDP household heads are earning 70\% of majority household heads in the labor market even though latter has only one year of additional education. We observe similar patterns between groups in Croatia, Montenegro and Serbia as well, as summarized in columns (4)-(12). Taken together, Table 1 suggests that Roma household heads are less equipped for the labor market; thus they are more likely to have adverse labor market experience both in terms of participation and earnings. On the other hand, it seems that RIDP household heads suffer in the local labor market despite their high levels of educational attainment. Likely mechanisms behind this penalty might be their lack of local labor market knowledge and ethnic networks or taste-based discrimination against them in the local labor market. Another potential explanation might be their limited ability to transfer the skills they acquired in their previous place of residence. Of course it is not possible 
to provide definitive proof of any of these stories, and undoubtedly additional mechanisms are at work too, but this seems to be plausible and important mechanisms for RIDP household heads' negative labor market experience (which we will rigorously elaborate in the empirical analysis).

In the next section, we will particularly focus on households with children in analyzing the intergenerational transmission of human capital over generations. Therefore, it is of interest to analyze whether the differences across groups summarized in Table 1 also prevail among household heads with children younger than 22 years of age residing within the same household. Table 2 reports the descriptive statistics for this subsample. Table 2 shows that approximately less than half of the household heads in our sample have young children residing within the same household. As expected, household heads with children are younger, more likely to be married, have larger household size, more likely to be employed, have higher household income and educational attainment relative to household heads without children. On the other hand, Table 2 points to even larger discrepancy in returns to education between majority and RIDPs. Table 2 reveals that in all four countries in our sample, RIDP household heads with children earn $40 \%$ $55 \%$ of the majority in the labor market and as a household income even though both groups have comparable educational attainment. This finding suggests that the earning penalty/loss among RIDPs generated by the displacement is even more striking when we focus only on household heads with children. Thus, this disparity in status of RIDP household heads raises concerns not only for household heads themselves but also for next generations' economic and social well-being.

Having shown the characteristics of household heads, we now turn to analysis of entire sample. Table 3 displays the characteristics of all individuals in our sample between age of 23 and 65. Table 3 mimics patterns presented in Table 1 and Table 2. Similar to previous tables, 
Table 3 also suggests that RIDPs resemble majority population in terms of marital status, educational attainment and number of children. Similar to majority population, RIDPs are also more likely to be high school graduate and have none or only one child. On the other hand, Roma people are more likely to have primary or elementary education and three children or more. For example, in Montenegro $70 \%$ of the Roma population has only primary education, where the average years of schooling for Roma is 3.94 years. In Bosnia and Herzegovina, Croatia and Serbia, the majority of Roma has elementary or secondary education, while only $1 \%$ of them have university degree compared to $25 \%-30 \%$ of majority and $5 \%-20 \%$ of RIDPs in these countries. Another striking pattern emerges from Table 3 is differences in employment probabilities between majority and two vulnerable groups. Table 3 shows that even though RIDPs look similar to majority in terms of education, their labor market attachment shows resemblance to Roma instead of majority population. In all countries, RIDPs are considerably less likely to be employed compared to majority despite the fact that they are more likely to work relative to Roma. A comparison of wage income across groups yields similar conclusion further suggesting that RIDPs indeed face hurdles not only in finding jobs but also in finding well-paid jobs in their new destination.

Tables (1)-(3) indicate that Roma people in our sample are generally younger than majority and RIDPs. Life Cycle Theory suggests that individuals' earnings and employment profile exhibit U-shape pattern. At the initial stage of life cycle, both employment and earning increases with age. However, the reverse is true at the later stage, where employment and earning decrease as individual ages. Therefore, it is of interest to analyze whether the aforementioned differences between groups in employment and earnings are driven by the differences in age distribution across groups. Analyses by age groups are summarized in Figures (1)-(3). Figure 1 
presents the average years of schooling by age groups for majority, RIDPs and Rome in four countries in our sample. In Bosnia and Herzegovina, Serbia and Montenegro, in all age groups, RIDPs have similar educational attainment as majority, which is substantially higher than Roma residing in their community. In addition, Figure 1 suggests that there is a less discrepancy between groups in terms of education in Croatia, where RIDPs older than 55 have similar educational attainment as Roma population.

Figure 2 illustrates the employment probabilities by age groups for majority population and the two vulnerable groups. In UNDP Survey, respondents were asked to report whether they are employed in formal or informal sector. This information is important since vulnerable groups are more likely to be employed in informal sector and focusing only on formal sector may yield to a downward estimate of employment among RIDPs and Roma households. Using this information in the survey, we coded individuals as employed if they have reported working in either formal or informal sector. To begin with, U-shape pattern emerged in Figure 2 confirms the life cycle theory. Indeed, probability of employment increases by age until age of 40-45 and decreases afterwards for all groups. Note however that there are stark differences at the employment probabilities across groups. At all age groups, majority population is substantially more likely to be employed compared to RIDPs and Roma. On the other hand, even though employment probabilities of RIDPs lie between majority and Roma, they are more likely to resemble Roma than majority in terms of their employment behavior.

Figure 2 shows that both RIDPs and Roma have weaker labor market attachment both in formal and informal sector which may lead to a higher poverty and vulnerability. However, focusing only on employment may be misleading since RIDPs and Roma are more likely to be on welfare and receive transfer payments compared to majority. In the survey, respondent were 
asked to report their household income from all sources including all kinds of wages, earnings, old age pension, disability pension, state transfer for children, unemployment, poverty and local assistance benefits, remittances or gifts received from friends and relatives and aids from NGOs, charitable or humanitarian contributions. To account for potential differences across households in labor market earnings, we generated a measure for household income from all sources using the aforementioned information in the survey. Figure 3 presents the average household income from all sources by age groups for all groups. We believe this measure will help us understand better the economic well-being of the vulnerable groups. It is striking that the same picture emerges as in employment when we focus on average household income for all sources. That is, similar to employment, both RIDPs and Roma households have considerably lower household income even when we account for welfare payments and other income sources. Figure 3 clearly illustrates that the household income of RIDPs are virtually similar to that of Roma and in most cases earn almost 50\% lower than the majority. ${ }^{2}$ Taken together, Figures (1)-(3) show that in all age groups, both Roma and RIDPs suffer in the local labor market despite latter have high levels of educational attainment.

Table 4 reports the summary statistics for children. We restrict our analysis to children who are between 6 and 22 years old and residing in the same household with their parents. Table 4 reveals that Roma children are almost a year younger, less likely to be female, have lower educational attainment and more likely to be out of school. Children from RIDPs households on the other hand, appear to be similar to children from majority households in terms of years of education, school attendance and demographic characteristics. Overall, this table hints that the lower household income in RIDPs households has no or limited adverse effects on children's human capital formation and vulnerability is likely to be limited to the current generation. In

\footnotetext{
${ }^{2}$ Figures are qualitatively similar if we use average individual income instead of average household income.
} 
contrast, in Roma households, vulnerability and lack of human capital had been transferred to next generations leaving this vulnerable group in the vicious cycle of poverty trap over generations.

\section{The Results}

\subsection{Income and Employment}

In the previous section, we presented descriptive characteristics for majority population, Roma and RIDPs in ex-Yugoslavian countries. As summarized above, all these groups differ in terms of their observable characteristics including educational attainment, marital status, number of children, and employment choices. In this section, we compare Roma and RIDPs' households income from all sources, monthly wage in household, and employment status relative to majority population. We present conditional means on these labor market measures using regression analysis, in which we compare Roma and RIDPs to majority after controlling for observable characteristics. We report the estimates from our empirical analysis in Table 5 and Table 6 using the 2004 UNDP dataset and follow the basic specifications for all groups' earnings equations widely applied in the literature: the variable of interest is regressed on individual characteristics such as gender, age, education, marital status, urban indicators, number of children; country dummies to control for fixed differences across countries (in regressions reported in column 1); and dummies for each group. The reported standard errors are clustered by country, accounting for the correlations in outcomes of individuals residing in the same country. The dependent variable is the natural logarithm of household income from all sources (in Table 5, Panel A), natural logarithm of household monthly wage income (in Table 5, Panel B), natural logarithm of individual income from all sources (in Table 5, Panel C), probability of employment (in Table 6 
Panel A), and the likelihood of unemployment (in Table 6 Panel B). In all these regressions, the omitted group is “majority population”. In all tables, the first row can be interpreted as the mean difference in the outcome of interest of Roma population with respect to majority population, once observable controls are included. Similarly, second row indicates the mean difference in outcomes between RIDPs and majority after controlling for differences in their characteristics.

Panel A of Table 5 reports the estimation results where the dependent variable is natural logarithm of household income from all sources. Each column is from a separate regression that controls for female and urban dummies along with marital status, educational attainment and number of children in the household. Table 5 suggests that Roma earn $50 \%$ less than majority population in their community even after controlling for potential differences in educational attainment and family size. The second row presents evidence on whether RIDPs households hold less income than majority population in the same community. Similar to Roma, RIDPs have also substantially lower household income relative majority population. Moreover, in most of the cases, the coefficient for Roma (first row) and RIDPs (second row) lie within each other's 95\% confidence interval suggesting that these two coefficients are statistically indistinguishable. Only exception is Bosnia and Herzegovina. It seems that in Bosnia and Herzegovina, even though RIDPs still have lower household income than majority, they fare better in the local market compared to Roma population in this country (column (2)).

After showing the estimation results for the household income from all sources, we next turn to analyzing the household income only from wage earnings (labor market earnings). Panel B of Table 5 presents the results when the outcome of interest is logarithm of household income from labor market. This household income measure is appealing to estimate to what extent one's human capital is rewarded in the local market holding other characteristics constant. It appears 
that although it is still negative and statistically significant, the magnitude of coefficient for RIDPs decreases once we restrict our analysis to labor market income. By contrast, however the coefficient for Roma becomes more negative when we focus on income from wages. Taken together, these changes in the coefficients hint that one of the reasons for the differences between groups may be that Roma are more likely to receive welfare and other source of income compared to RIDPs that are probably less aware of welfare opportunities in their new destination.

As an additional outcome, we also examine the logarithm of individual income from all sources, summarized in Panel C. Since there are differences in household size across groups, a comparison of individual incomes may yield a clearer picture on the vulnerability of Roma and RIDPs. The analysis reported in Panel C mimics the previous findings on household income, summarized in Panel A and Panel B. Similarly, both individuals from Roma and RIDP households have lower individual income from all sources after differences in demographic characteristics and educational attainment is taken into account. The first and second rows show that Roma and RIDPs receive $27 \%$ and $25 \%$ less individual income , respectively, compared to otherwise comparable majority population in the same community. These coefficients are half the size of the estimates for household income presented in Panel A. Though it is beyond the scope of this chapter to disentangle the underlying mechanisms responsible for this difference; we may suggest several explanations. One potential reason would be the child employment and state transfer for children. Of course we have no definitive proof, but it might be that majority population is more likely to receive state transfer for children, and their working-age children (young adults) are more likely to engage in labor market activities compared to working-age children (young adults) from Roma and RIDPs households. The analysis from Table 4 on 
working-age child (young adult) employment suggests that this would be one of the explanations. Another explanation would be the employment of other household members. It might be that members of majority population are more likely to have spouses who are more educated and more likely to be working compared to the vulnerable groups. Under this scenario, the vulnerable households are likely to experience double disadvantage, one due to discrimination and another due to the household composition.

As final outcomes in this section, we estimate the employment probability and unemployment, which are presented in Table 6. These regressions are at the individual level and reports whether individuals between 23 and 65 years old work either in formal or informal sector. We find that adults in Roma households are $16 \%$ less likely to engage in labor market activity compared to members of majority population. The corresponding difference between employment probabilities of RIDPs and majority population is $14 \%$. Similar to findings on household income in Table 5, for employment probability, the coefficients for Roma and RIDPS are virtually similar as well (they lie within each other’s 95\% confidence interval). On the other hand, Panel B of Table 6 displays the findings for unemployment. We define unemployment measure using individuals who are actively looking for job; therefore our measure excludes discouraged workers and individuals that are out of labor force. Findings in Panel B of Table 6 further confirm previous findings on employment. Both Roma and RIDPs are more likely to be unemployed compared to majority residing in the same community. Thus, when we consider findings in Table 6 together; we ascertain that members of two vulnerable groups disproportionately suffer in the labor market even when they exhibit the characteristics of majority population. Moreover, our analysis also suggests that these vulnerable groups are not only less likely to find jobs in the local labor market due to discrimination or lack of social 
networks but also less likely to find well-paid jobs since the differences between groups are even larger when we focus on income.

\subsection{Education and Intergenerational Transfer of Human Capital}

To evaluate the long-run effects of vulnerability, in this section we explore the results from the analysis of educational attainment of children between 6 and 22 years of age residing in the same household. We first look at the vulnerability along children's educational attainment measured by being out of education. As evident from column 1 of Table 7, being a Roma increases the probability of being out of education by about 31 per cent. The corresponding probability for RIDPs is 13 per cent. Similar results arise if we look at years of education in column 1 of Table 8. Being a Roma or RIDP reduces educational attainment by 1.68 and 0.30 years, respectively. All these effects are statistically significant at 1 per cent confidence level. Regardless of the outcome we look at, child's age plays a significant role as expected, whereas age of the household head turns insignificant. Children in households with higher income appear to have better educational prospects.

Looking at intergenerational transfer of human capital measured by the effect of the household head's educational attainment on children's human capital formation, we find a strong positive effect. In particular, every additional year of household head's schooling reduces the child's probability of being out of education by 4 per cent and increases the expected educational attainment of children by 0.26 years. This high intergenerational transfer of human capital may hide important differences between the majority and vulnerable groups studied. We investigate this possibility in Panel B of Table 7 and Table 8. While we do not observe any such differences in the model with being out of education as the explained variable, we find that intergenerational 
transfer of human capital is about twice as strong for vulnerable groups than for the majority population when children's educational attainment is measured by years of education. This finding suggests that the vulnerability is likely being transferred over generations, where less educated parents raise children with lower human capital endowments.

Pooling the countries and groups of people into a single regression may hide important differences in the effects studied if the true models differ across groups and countries. Looking at Columns (2) - (5) in Table 7 and 8 where we report the results for children's years of education, it is immediately obvious that vulnerability manifests itself in all the countries under scrutiny and for both the Roma and RIDPs. In all countries the effect of being Roma is larger than that of being an RIDP but Montenegro. The observed effects for RIDPs are in fact not significant in Croatia, Montenegro and Serbia. Intergenerational transfer of human capital is positive across the board, but important differences arise between the studied groups of people.

In Bosnia significantly positive effects are observed only for Roma. Croatia exhibits similar results, but event the effects for Roma are only marginally significant. In Serbia all groups exhibit about the same positive and significant effects. In Montenegro, positive and significant effects are observed only for the two vulnerable groups.

\section{Conclusions and Policy Recommendations}

This chapter elucidates the current and future prospects of vulnerable groups in the context of former Yugoslavia. We find that vulnerability is associated with significantly substandard income and employment prospects. As we do not find much residual difference between the Roma and the RIDPs, we offer some evidence that that vulnerability inflicted by relatively recent displacement may have similar effects as vulnerability rooted deep in the past. 
To the extent that the Yugoslav wars can be treated as exogenous and acknowledging the limitations of our study in that we cannot observe socio-economic outcomes before the wars, our results hint at causal interpretation of the effects of vulnerability.

Our results show that being a member of a vulnerable group manifests itself also through the educational attainment of children. It is worrying that vulnerable groups seem to be entrapped in this adverse situation, as the link through which lower educational attainment of parents affects children's educational attainment seems to be particularly strong for them.

Comparing the two different genealogies of vulnerability, it seems that the Roma who have been in a vulnerable position before as well as after the armed conflicts of the 1990s in Yugoslavia are in a worse position than the RIDPs who had not been vulnerable ex-ante but their displacement as a consequence of the armed conflicts have put them in a vulnerable position. This together with the particularly substandard educational outcomes of the Roma parents indicates that this entrapment is more severe for this group and may be an artifact of historically deep-entrenched vulnerability.

From the policy perspective, these results show that while violent conflict can put large groups of people into a vulnerable position, the prospects of people whose vulnerability is deeprooted historically are at a significantly higher risk of a dynamic trap whereby parents' outcomes determine children's outcomes. In the educational domain, this indicates that policy efforts directed at RIDPs' integration need to focus on childrens' access to education, whereas for the Roma also the parents and the mechanisms through which parents affect children's outcomes must be given significant attention. This could entail life-long education of the parents, or specialized field workers working with the parents and enabling them to e.g. help their children with homework assignments. For the RIDPs the policy efforts to facilitate access to education 
would need to address the specific situation of RIDPs households case by case, which could include poor infrastructure, lack of social contacts, poor housing and access to health, lack of documents, or insufficient social assistance and services when in need. 


\section{References:}

Akbulut-Yuksel, Mevlude. 2009. "Children of war: The long-run effects of large-scale physical destruction and warfare on children.” IZA Discussion Papers, No. 4407. IZA, Bonn

Angrist, Joshua and Adriana Kugler. 2008. "Rural Windfall or Resource Curse? Coca, Income and Civil Conflict in Colombia.” Review of Economics and Statistics, 90 (2): 191-215.

Brakman, Steven; Garretsen, Harry and Schramm, Marc. 2004. "The Strategic Bombing of Cities in Germany in World War II and it Impact on City Growth.” Journal of Economic Geography,, 4(1), pp. 1-18.

Constant, Amelie F. and Klaus F. Zimmermann. 2008. "Measuring Ethnic Identity and its Impact on Economic Behavior," Journal of the European Economic Association, MIT Press, vol. 6(2-3), pages 424-433, 04-05.

Davis, Donald, and Weinstein, David. 2002. "Bones, Bombs, and Break Points: The Geography of Economic Activity.” American Economic Review, 92(5), pp. 1269-1289.

Fraser Angus. 1992. The Gypsies. Oxford:Blackwell.

Florence Kondylis. "Conflict displacement and labor market outcomes in post-war Bosnia and Herzegovina.” Journal of Development Economics , forthcoming

Ichino, Andrea and Winter-Ebmer, Rudolf. 2004. "The Long-Run Educational Cost of World War II.” Journal of Labor Economics, 22(1), pp. 57-86.

Milcher Susanne. 2006. "Poverty and the Determinants of Welfarefor Roma and Other Vulnerable Groups inSoutheastern Europe” Comparative Economic Studies, 48, (20-35).

Milcher and Zigová .2005. “Evidence of Returns to Education Among Roma in Central and Eastern Europe and Their Policy Implications", International Research Journal volume 3 • number $1 \cdot$ spring.

Miguel, Edward and Gerard Roland. 2006 “The Long Run Impact of Bombing Vietnam.” University of California, Berkeley manuscript.

O’Higgins, N. and Ivanov, A. 2006: “Education and employment opportunities for the Roma.” Comparative Economic Studies 48(1): 6-19.

Shemyakina, Olga.2006. “The Effect of Armed Conflict on Accumulation of Schooling: Results from Tajikistan.” Households in Conflict Network Working Paper: No. 12.

Swee Eik.2009. “On War and Schooling Attainment: The Case of Bosnia and Herzegovina”, Households in Conflict Network (HiCN) Working Paper 57. 
Organski, A.F.K., and J. Kugler .1977. "The Costs of Major Wars: The Phoenix Factor," American Political Science Review 71:1347-1366.

Organski, A.F.K., and J. Kugler .1980. The War Ledger. Chicago: University of Chicago Press.

Owen R. C. 1997a: “The Balkans Air Campaign Study: Part One,” Airpower Journal, 11(2), 425.

Owen, R. C. 1997b: “The Balkans Air Campaign Study: Part Two,” Airpower Journal, 11(3), 627.

UNDP. 2006. At Risk: Roma and the Displaced in Southeast Europe, Bratislava Regional Centre

UN High Commissioner for Refugees. 1998. Guiding Principles on Internal Displacement, E/CN.4/1998/53/Add.2, available at: http://www.unhcr.org/refworld/docid/3c3da07f7.html [accessed 30 July 2010]

Valentina Calderón and Ana María Ibáñez, 2009. "Labor Market Effects of Migration-Related Supply Shocks: Evidence from Internally Displaced Populations in Colombia," Research Working Papers 14, MICROCON - A Micro Level Analysis of Violent Conflict.

Vulliamy E. 1994: Seasons in Hell: Understanding Bosnia’s War. St. Martin’s Press, New York. 
Table 1: Summary Statistics for Household Heads

\begin{tabular}{|c|c|c|c|c|c|c|c|c|c|c|c|c|}
\hline & \multicolumn{3}{|c|}{ Bosnia \& Hertzegovina } & \multicolumn{3}{|c|}{ Croatia } & \multicolumn{3}{|c|}{ Montenegro } & \multicolumn{3}{|c|}{ Serbia } \\
\hline & $\frac{\text { Majority }}{(1)}$ & $\frac{\text { Roma }}{(2)}$ & $\frac{\text { R\&IDPs }}{(3)}$ & $\frac{\text { Majority }}{(4)}$ & $\frac{\text { Roma }}{(5)}$ & $\frac{\text { R\&IDPs }}{(6)}$ & $\frac{\text { Majority }}{(7)}$ & $\frac{\text { Roma }}{(8)}$ & $\frac{\text { R\&IDPs }}{(9)}$ & $\frac{\text { Majority }}{(10)}$ & $\frac{\text { Roma }}{(11)}$ & $\frac{\text { R\&IDPs }}{(12)}$ \\
\hline Age & 49.30 & 43.61 & 48.74 & 49.12 & 37.27 & 49.94 & 49.71 & 46.97 & 50.38 & 49.20 & 46.40 & 48.66 \\
\hline Female & 23.02 & 24.50 & 34.92 & 41.47 & 11.37 & 26.26 & 18.69 & 22.33 & 18.63 & 25.99 & 16.50 & 17.78 \\
\hline Years of Schooling & 11.33 & 4.59 & 9.76 & 11.35 & 6.32 & 8.97 & 12.51 & 3.17 & 11.44 & 12.12 & 6.45 & 10.67 \\
\hline Primary School & 18.56 & 86.00 & 37.94 & 23.35 & 81.70 & 49.74 & 9.64 & 94.50 & 23.27 & 13.12 & 75.19 & 27.90 \\
\hline Secondary School & 57.92 & 13.75 & 50.00 & 54.09 & 17.45 & 46.11 & 58.88 & 5.50 & 53.96 & 57.18 & 22.56 & 49.88 \\
\hline Tertiary & 23.51 & 0.25 & 12.06 & 22.57 & 0.85 & 4.15 & 31.47 & 0.00 & 22.77 & 29.70 & 2.26 & 22.22 \\
\hline Married & 71.78 & 72.75 & 64.07 & 59.69 & 87.45 & 69.19 & 73.74 & 73.79 & 73.04 & 70.05 & 79.75 & 76.30 \\
\hline Urban & 70.30 & 53.00 & 61.31 & 30.71 & 20.24 & 17.77 & 36.87 & 23.12 & 37.25 & 78.20 & 79.70 & 66.50 \\
\hline Family Size & 3.07 & 4.85 & 3.47 & 2.81 & 4.97 & 3.33 & 3.54 & 3.51 & 3.47 & 3.18 & 4.41 & 3.85 \\
\hline Number of Children & 0.18 & 1.24 & 0.42 & 0.20 & 1.75 & 0.47 & 0.26 & 1.06 & 0.43 & 0.21 & 1.02 & 0.72 \\
\hline Employed & 48.02 & 12.25 & 31.91 & 54.65 & 23.14 & 33.33 & 59.09 & 17.96 & 37.75 & 54.95 & 24.75 & 31.36 \\
\hline Income & $\begin{array}{c}237.39 \\
(180.24)\end{array}$ & $\begin{array}{c}132.63 \\
(116.12)\end{array}$ & $\begin{array}{c}177.56 \\
(109.47)\end{array}$ & $\begin{array}{c}480.00 \\
(406.54)\end{array}$ & $\begin{array}{c}435.15 \\
(831.65)\end{array}$ & $\begin{array}{c}301.97 \\
(258.21)\end{array}$ & $\begin{array}{c}285.21 \\
(219.08)\end{array}$ & $\begin{array}{l}147.85 \\
(98.82)\end{array}$ & $\begin{array}{c}195.77 \\
(105.48)\end{array}$ & $\begin{array}{c}217.33 \\
(179.13)\end{array}$ & $\begin{array}{c}128.14 \\
(202.36)\end{array}$ & $\begin{array}{c}140.80 \\
(111.94)\end{array}$ \\
\hline Household Income-Wage & $\begin{array}{c}292.12 \\
(267.12)\end{array}$ & $\begin{array}{c}89.87 \\
(174.61)\end{array}$ & $\begin{array}{c}205.50 \\
(200.61)\end{array}$ & $\begin{array}{c}622.01 \\
(659.82)\end{array}$ & $\begin{array}{c}183.54 \\
(342.81)\end{array}$ & $\begin{array}{c}249.81 \\
(353.88)\end{array}$ & $\begin{array}{c}407.57 \\
(317.13)\end{array}$ & $\begin{array}{c}117.27 \\
(102.27)\end{array}$ & $\begin{array}{c}203.14 \\
(190.86)\end{array}$ & $\begin{array}{c}252.91 \\
(243.72)\end{array}$ & $\begin{array}{c}103.21 \\
(169.90)\end{array}$ & $\begin{array}{c}148.54 \\
(228.12)\end{array}$ \\
\hline Household Income-All Sources & $\begin{array}{c}355.56 \\
(252.06)\end{array}$ & $\begin{array}{c}193.62 \\
(208.78)\end{array}$ & $\begin{array}{c}281.31 \\
(190.50)\end{array}$ & $\begin{array}{c}789.83 \\
(667.20)\end{array}$ & $\begin{array}{c}435.32 \\
(377.31)\end{array}$ & $\begin{array}{c}398.05 \\
(344.80)\end{array}$ & $\begin{array}{c}497.64 \\
(319.30)\end{array}$ & $\begin{array}{c}197.02 \\
(164.55)\end{array}$ & $\begin{array}{c}260.92 \\
(229.93)\end{array}$ & $\begin{array}{c}376.26 \\
(272.27)\end{array}$ & $\begin{array}{c}170.28 \\
(192.19)\end{array}$ & $\begin{array}{c}229.51 \\
(268.77)\end{array}$ \\
\hline $\mathrm{N}$ & 404 & 400 & 398 & 258 & 255 & 198 & 198 & 206 & 204 & 404 & 400 & 405 \\
\hline
\end{tabular}

Notes:The table includes percentages, means and standard deviations for household heads between the ages of 23 and 65 using the 2004 UNDP data set. Income variables are in Euros. 
Table 2: Summary Statistics for Household Heads with Children

\begin{tabular}{|c|c|c|c|c|c|c|c|c|c|c|c|c|}
\hline & \multicolumn{3}{|c|}{ Bosnia \& Hertzegovina } & \multicolumn{3}{|c|}{ Croatia } & \multicolumn{3}{|c|}{ Montenegro } & \multicolumn{3}{|c|}{ Serbia } \\
\hline & $\frac{\text { Majority }}{(1)}$ & $\frac{\text { Roma }}{(2)}$ & $\frac{\text { R\&IDPs }}{(3)}$ & $\frac{\text { Majority }}{(4)}$ & $\frac{\text { Roma }}{(5)}$ & $\frac{\text { R\&IDPs }}{(6)}$ & $\frac{\text { Majority }}{(7)}$ & $\frac{\text { Roma }}{(8)}$ & $\frac{\text { R\&IDPs }}{(9)}$ & $\frac{\text { Majority }}{(10)}$ & $\frac{\text { Roma }}{(11)}$ & $\frac{\text { R\&IDPs }}{(12)}$ \\
\hline Age & 45.13 & 41.39 & 44.28 & 44.16 & 37.67 & 42.28 & 47.29 & 43.40 & 48.03 & 46.23 & 41.86 & 43.39 \\
\hline Female & 18.88 & 23.53 & 35.59 & 30.88 & 7.23 & 15.79 & 12.77 & 7.14 & 14.13 & 19.02 & 9.85 & 14.42 \\
\hline Years of Schooling & 11.59 & 4.79 & 10.31 & 11.88 & 6.50 & 9.93 & 12.83 & 3.94 & 11.45 & 12.34 & 7.06 & 10.98 \\
\hline Primary School & 13.99 & 83.61 & 33.90 & 13.24 & 79.62 & 37.33 & 6.38 & 92.65 & 20.88 & 9.82 & 72.91 & 25.58 \\
\hline Secondary School & 65.73 & 16.39 & 54.24 & 67.65 & 19.75 & 58.67 & 57.45 & 7.35 & 57.14 & 57.06 & 25.12 & 51.16 \\
\hline Tertiary & 20.28 & 0.00 & 11.86 & 19.12 & 0.64 & 4.00 & 36.17 & 0.00 & 21.98 & 33.13 & 1.97 & 23.26 \\
\hline Married & 86.71 & 76.47 & 70.62 & 88.24 & 93.37 & 85.53 & 87.23 & 92.86 & 83.70 & 85.28 & 87.68 & 86.98 \\
\hline Urban & 70.63 & 48.74 & 59.89 & 35.29 & 23.49 & 14.47 & 36.17 & 38.57 & 38.04 & 79.75 & 73.89 & 66.05 \\
\hline Family Size & 3.98 & 5.94 & 4.15 & 4.16 & 5.69 & 4.57 & 4.15 & 5.67 & 4.05 & 3.91 & 4.94 & 4.59 \\
\hline Number of Children & 0.39 & 1.78 & 0.62 & 0.46 & 2.19 & 1.01 & 0.30 & 2.17 & 0.58 & 0.29 & 1.28 & 1.08 \\
\hline Employed & 62.24 & 13.45 & 37.85 & 73.53 & 27.11 & 39.47 & 80.85 & 34.29 & 45.65 & 69.94 & 31.53 & 36.74 \\
\hline Income & $\begin{array}{c}262.12 \\
(166.38)\end{array}$ & $\begin{array}{c}133.53 \\
(114.18)\end{array}$ & $\begin{array}{c}191.60 \\
(112.66)\end{array}$ & $\begin{array}{c}530.39 \\
(315.81)\end{array}$ & $\begin{array}{c}482.08 \\
(903.79)\end{array}$ & $\begin{array}{c}366.01 \\
(299.06)\end{array}$ & $\begin{array}{c}336.29 \\
(268.66)\end{array}$ & $\begin{array}{c}188.67 \\
(106.02)\end{array}$ & $\begin{array}{c}221.68 \\
(125.18)\end{array}$ & $\begin{array}{c}217.29 \\
(145.79)\end{array}$ & $\begin{array}{c}156.82 \\
(261.90)\end{array}$ & $\begin{array}{l}130.52 \\
(98.53)\end{array}$ \\
\hline Household Income-Wage & $\begin{array}{c}365.08 \\
(277.59)\end{array}$ & $\begin{array}{c}100.98 \\
(200.80)\end{array}$ & $\begin{array}{c}201.98 \\
(194.42)\end{array}$ & $\begin{array}{c}837.93 \\
(615.34)\end{array}$ & $\begin{array}{c}183.02 \\
(341.53)\end{array}$ & $\begin{array}{c}351.50 \\
(402.80)\end{array}$ & $\begin{array}{c}491.31 \\
(319.60)\end{array}$ & $\begin{array}{c}162.13 \\
(130.07)\end{array}$ & $\begin{array}{c}230.97 \\
(202.92)\end{array}$ & $\begin{array}{c}292.42 \\
(227.83)\end{array}$ & $\begin{array}{c}122.07 \\
(218.03)\end{array}$ & $\begin{array}{c}148.14 \\
(262.33)\end{array}$ \\
\hline Household Income-All Sources & $\begin{array}{c}410.73 \\
(266.43)\end{array}$ & $\begin{array}{c}202.98 \\
(226.83)\end{array}$ & $\begin{array}{c}267.07 \\
(168.24)\end{array}$ & $\begin{array}{c}934.45 \\
(557.33)\end{array}$ & $\begin{array}{c}455.01 \\
(308.96)\end{array}$ & $\begin{array}{c}513.34 \\
(390.37)\end{array}$ & $\begin{array}{c}552.37 \\
(332.03)\end{array}$ & $\begin{array}{c}249.84 \\
(186.87)\end{array}$ & $\begin{array}{c}279.86 \\
(291.23)\end{array}$ & $\begin{array}{c}390.87 \\
(261.77)\end{array}$ & $\begin{array}{c}181.47 \\
(239.14)\end{array}$ & $\begin{array}{c}210.36 \\
(294.91)\end{array}$ \\
\hline $\mathrm{N}$ & 143 & 238 & 177 & 68 & 166 & 76 & 94 & 70 & 92 & 163 & 203 & 215 \\
\hline
\end{tabular}

Notes:The table includes percentages, means and standard deviations for household heads between the ages of 23 and 65 using the 2004 UNDP data set. Income variables are in Euros. 
Table 3: Summary Statistics for All Adults

\begin{tabular}{|c|c|c|c|c|c|c|c|c|c|c|c|c|}
\hline & \multicolumn{3}{|c|}{ "Bosnia \& Hertzegovina } & \multicolumn{3}{|c|}{ Croatia } & \multicolumn{3}{|c|}{ Montenegro } & \multicolumn{3}{|c|}{ Serbia } \\
\hline & Majority & $\underline{\text { Roma }}$ & $\underline{\text { R\&IDPs }}$ & Majority & $\underline{\text { Roma }}$ & $\underline{\text { R\&IDPs }}$ & Majority & Roma & $\underline{\text { R\&IDPs }}$ & Majority & $\underline{\text { Roma }}$ & $\underline{\text { R\&IDPs }}$ \\
\hline & (1) & $(2)$ & (3) & (4) & (5) & (6) & (7) & (8) & (9) & (10) & (11) & $(12)$ \\
\hline Female & 52.42 & 49 & 52.35 & 52.87 & 49.44 & 50.91 & 51.02 & 48.04 & 49 & 50.14 & 46.49 & 49.15 \\
\hline Age & 38.72 & 33.5 & 37.32 & 37.9 & 31.92 & 37.83 & 38.89 & 36.22 & 37.17 & 36.56 & 34.52 & 37.68 \\
\hline Married & 68.82 & 69.13 & 63.76 & 63.64 & 84.82 & 71.58 & 64.73 & 79.75 & 70.55 & 66.38 & 75.52 & 65.64 \\
\hline Employed & 41.97 & 7.07 & 29.97 & 57.58 & 18.22 & 32.17 & 52.28 & 16.46 & 26.16 & 53.23 & 17.61 & 31.28 \\
\hline \multicolumn{13}{|c|}{ Highest Degree Completed } \\
\hline Primary School & 17.98 & 87.25 & 32.96 & 13.58 & 84.63 & 45.59 & 11.96 & 78.12 & 26.18 & 8.29 & 94.58 & 16.63 \\
\hline Secondary School & 58.62 & 12.51 & 54.1 & 57.92 & 13.76 & 49.71 & 57.95 & 20.68 & 53.2 & 59.68 & 5.42 & 61.76 \\
\hline Tertiary & 23.4 & 0.24 & 12.94 & 28.51 & 1.61 & 4.71 & 30.09 & 1.2 & 20.63 & 32.03 & 0 & 21.62 \\
\hline \multicolumn{13}{|l|}{$\underline{\text { Number of Children }}$} \\
\hline Zero & 61.63 & 27 & 51.01 & 64.17 & 13.1 & 54.31 & 58.65 & 29.57 & 41.94 & 48.48 & 50.75 & 50.98 \\
\hline One & 19.55 & 16.25 & 18.84 & 16.93 & 15.87 & 18.78 & 23.06 & 19.05 & 21.34 & 24.75 & 13.07 & 20.1 \\
\hline Two & 14.85 & 20 & 22.11 & 15.75 & 23.8 & 16.24 & 16.79 & 26.07 & 20.35 & 19.7 & 11.56 & 19.61 \\
\hline Three+ & 3.97 & 36.75 & 8.04 & 3.15 & 47.23 & 10.67 & 1.5 & 25.31 & 16.37 & 7.07 & 24.62 & 9.31 \\
\hline
\end{tabular}

Notes: The table includes percentages, means and standard deviations for household heads between the ages of 23 and 65 using the 2004 UNDP data set. Income variables are in Euros. 
Table 4: Summary Statistics for Children

\begin{tabular}{|c|c|c|c|c|c|c|c|c|c|c|c|c|}
\hline & \multicolumn{3}{|c|}{ "Bosnia \& Hertzegovina } & \multicolumn{3}{|c|}{ Croatia } & \multicolumn{3}{|c|}{ Montenegro } & \multicolumn{3}{|c|}{ Serbia } \\
\hline & Majority & $\underline{\text { Roma }}$ & $\underline{\text { R\&IDPs }}$ & Majority & $\underline{\text { Roma }}$ & $\underline{\text { R\&IDPs }}$ & Majority & $\underline{\text { Roma }}$ & $\underline{\text { R\&IDPs }}$ & Majority & $\underline{\text { Roma }}$ & $\underline{\text { R\&IDPs }}$ \\
\hline & (1) & (2) & (3) & (4) & (5) & (6) & (7) & (8) & (9) & (10) & (11) & $(12)$ \\
\hline Age & 14.85 & 13.67 & 15.14 & 14.13 & 12.88 & 13.74 & 16.03 & 13.97 & 14.09 & 15.78 & 14.08 & 15.35 \\
\hline Female & 53.64 & 44.80 & 46.03 & 45.79 & 48.41 & 49.65 & 46.19 & 45.34 & 41.90 & 44.17 & 38.07 & 41.18 \\
\hline Years of Schooling & 7.85 & 3.13 & 7.54 & 7.70 & 4.80 & 6.50 & 8.63 & 4.58 & 6.52 & 8.87 & 3.04 & 7.77 \\
\hline Primary School & 50.00 & 92.48 & 54.92 & 58.16 & 89.92 & 66.39 & 50.00 & 90.91 & 63.57 & 39.26 & 92.94 & 55.56 \\
\hline Secondary School & 37.27 & 7.36 & 36.51 & 37.76 & 9.81 & 31.09 & 34.32 & 8.35 & 32.25 & 46.63 & 5.88 & 34.64 \\
\hline Tertiary & 12.73 & 0.16 & 8.57 & 4.08 & 0.27 & 2.52 & 15.68 & 0.74 & 4.18 & 14.11 & 1.18 & 9.80 \\
\hline Married & 0.00 & 3.04 & 0.00 & 0.00 & 3.91 & 0.71 & 1.69 & 5.15 & 0.69 & 0.00 & 3.41 & 0.00 \\
\hline Employed & 2.27 & 0.16 & 3.81 & 8.41 & 2.93 & 4.96 & 5.51 & 3.43 & 1.39 & 6.13 & 5.68 & 4.58 \\
\hline $\mathrm{N}$ & 220 & 625 & 315 & 107 & 409 & 141 & 236 & 408 & 432 & 163 & 176 & 153 \\
\hline
\end{tabular}

Notes:The table includes percentages, means and standard deviations for children between the ages of 6 and 22 using the 2004 UNDP data set. 
Table 5: Estimates for Income

\begin{tabular}{|c|c|c|c|c|c|}
\hline & All & Bosnia & Croatia & Serbia & Montenegro \\
\hline & (1) & (2) & (3) & (4) & (5) \\
\hline & \multicolumn{5}{|c|}{ Panel A. Household income-all sources } \\
\hline Roma & $\begin{array}{c}-0.493 * * * \\
(0.033)\end{array}$ & $\begin{array}{c}-0.515^{* * *} \\
(0.079)\end{array}$ & $\begin{array}{c}-0.517 * * * \\
(0.117)\end{array}$ & $\begin{array}{c}-0.458 * * * \\
(0.078)\end{array}$ & $\begin{array}{c}-0.542^{* * * *} \\
(0.144)\end{array}$ \\
\hline Refugee \& IDPs & $\begin{array}{c}-0.454^{* *} \\
(0.135)\end{array}$ & $\begin{array}{c}-0.174^{* * *} \\
(0.052)\end{array}$ & $\begin{array}{c}-0.608^{* * *} \\
(0.098)\end{array}$ & $\begin{array}{c}-0.529 * * * \\
(0.066)\end{array}$ & $\begin{array}{c}-0.736^{* * * *} \\
(0.074)\end{array}$ \\
\hline Female & $\begin{array}{c}0.044 \\
(0.071)\end{array}$ & $\begin{array}{l}0.124^{*} \\
(0.069)\end{array}$ & $\begin{array}{l}-0.015 \\
(0.091)\end{array}$ & $\begin{array}{l}-0.093 \\
(0.089)\end{array}$ & $\begin{array}{l}-0.008 \\
(0.133)\end{array}$ \\
\hline Married & $\begin{array}{c}0.254^{* *} \\
(0.049)\end{array}$ & $\begin{array}{c}0.343^{* * *} \\
(0.065)\end{array}$ & $\begin{array}{c}0.116 \\
(0.093)\end{array}$ & $\begin{array}{c}0.195^{* *} \\
(0.085)\end{array}$ & $\begin{array}{c}0.265^{* *} \\
(0.119)\end{array}$ \\
\hline Urban & $\begin{array}{c}0.006 \\
(0.026)\end{array}$ & $\begin{array}{l}-0.033 \\
(0.046)\end{array}$ & $\begin{array}{c}0.000 \\
(0.076)\end{array}$ & $\begin{array}{c}0.044 \\
(0.067)\end{array}$ & $\begin{array}{c}0.014 \\
(0.067)\end{array}$ \\
\hline Secondary School & $\begin{array}{c}0.425^{* * *} \\
(0.064)\end{array}$ & $\begin{array}{c}0.299 * * * \\
(0.069)\end{array}$ & $\begin{array}{c}0.512^{* * *} \\
(0.093)\end{array}$ & $\begin{array}{c}0.505^{* * *} \\
(0.075)\end{array}$ & $\begin{array}{c}0.454^{* * *} \\
(0.131)\end{array}$ \\
\hline Tertiary & $\begin{array}{c}0.753^{* * * *} \\
(0.077)\end{array}$ & $\begin{array}{c}0.673 * * * \\
(0.083)\end{array}$ & $\begin{array}{c}0.951^{* * * *} \\
(0.127)\end{array}$ & $\begin{array}{c}0.845^{* * * *} \\
(0.092)\end{array}$ & $\begin{array}{c}0.599 * * * * \\
(0.138)\end{array}$ \\
\hline Number of Children & $\begin{array}{c}0.012 \\
(0.030)\end{array}$ & $\begin{array}{c}0.013 \\
(0.019)\end{array}$ & $\begin{array}{c}0.126 * * * \\
(0.022)\end{array}$ & $\begin{array}{l}-0.035 \\
(0.023)\end{array}$ & $\begin{array}{l}-0.050^{*} \\
(0.028)\end{array}$ \\
\hline \multirow[t]{2}{*}{$\mathrm{N}$} & 3,015 & 1,038 & 511 & 989 & 477 \\
\hline & \multicolumn{5}{|c|}{ Panel B.Household Income-Wage } \\
\hline Roma & $\begin{array}{c}-0.559 * * \\
(0.106)\end{array}$ & $\begin{array}{c}-0.628 * * * \\
(0.084)\end{array}$ & $\begin{array}{c}-0.343^{* *} \\
(0.154)\end{array}$ & $\begin{array}{c}-0.466^{* * *} \\
(0.087)\end{array}$ & $\begin{array}{c}-0.918 * * * \\
(0.156)\end{array}$ \\
\hline Refugee \& IDPs & $\begin{array}{c}-0.397^{* *} \\
(0.117)\end{array}$ & $\begin{array}{c}-0.169 * * * \\
(0.055)\end{array}$ & $\begin{array}{c}-0.369 * * * \\
(0.108)\end{array}$ & $\begin{array}{c}-0.519 * * * \\
(0.069)\end{array}$ & $\begin{array}{c}-0.601^{* * * *} \\
(0.076)\end{array}$ \\
\hline Female & $\begin{array}{c}0.034 \\
(0.078)\end{array}$ & $\begin{array}{l}0.130^{*} \\
(0.074)\end{array}$ & $\begin{array}{l}-0.022 \\
(0.094)\end{array}$ & $\begin{array}{l}-0.096 \\
(0.090)\end{array}$ & $\begin{array}{c}0.113 \\
(0.186)\end{array}$ \\
\hline Married & $\begin{array}{c}0.214^{* *} \\
(0.057)\end{array}$ & $\begin{array}{c}0.256^{* * *} \\
(0.073)\end{array}$ & $\begin{array}{c}0.117 \\
(0.101)\end{array}$ & $\begin{array}{c}0.119 \\
(0.092)\end{array}$ & $\begin{array}{l}0.413^{* *} \\
(0.174)\end{array}$ \\
\hline Urban & $\begin{array}{c}0.043 \\
(0.062)\end{array}$ & $\begin{array}{l}-0.091^{*} \\
(0.051)\end{array}$ & $\begin{array}{c}0.093 \\
(0.090)\end{array}$ & $\begin{array}{c}0.101 \\
(0.079)\end{array}$ & $\begin{array}{c}0.081 \\
(0.071)\end{array}$ \\
\hline Secondary School & $\begin{array}{c}0.406 * * * \\
(0.068)\end{array}$ & $\begin{array}{c}0.264 * * * \\
(0.080)\end{array}$ & $\begin{array}{c}0.510^{* * * *} \\
(0.122)\end{array}$ & $\begin{array}{c}0.471^{* * *} \\
(0.083)\end{array}$ & $\begin{array}{c}0.374 * * * \\
(0.143)\end{array}$ \\
\hline Tertiary & $\begin{array}{c}0.782 * * * \\
(0.074)\end{array}$ & $\begin{array}{c}0.688^{* * * *} \\
(0.088)\end{array}$ & $\begin{array}{c}0.907 * * * \\
(0.150)\end{array}$ & $\begin{array}{c}0.892^{* * *} \\
(0.097)\end{array}$ & $\begin{array}{c}0.567 * * * \\
(0.158)\end{array}$ \\
\hline Number of Children & $\begin{array}{l}-0.026 \\
(0.021)\end{array}$ & $\begin{array}{l}-0.006 \\
(0.024)\end{array}$ & $\begin{array}{c}0.030 \\
(0.036)\end{array}$ & $\begin{array}{c}-0.064 * * \\
(0.028)\end{array}$ & $\begin{array}{l}-0.052^{*} \\
(0.030)\end{array}$ \\
\hline $\mathrm{N}$ & 2,302 & 741 & 325 & 815 & 421 \\
\hline & \multicolumn{5}{|c|}{ Panel C. Individual Income-All Sources } \\
\hline Roma & $\begin{array}{l}-0.271^{*} \\
(0.096)\end{array}$ & $\begin{array}{c}-0.476 * * * \\
(0.070)\end{array}$ & $\begin{array}{l}-0.071 \\
(0.123)\end{array}$ & $\begin{array}{c}-0.222 * * * \\
(0.066)\end{array}$ & $\begin{array}{l}-0.210^{*} \\
(0.124)\end{array}$ \\
\hline Refugee \& IDPs & $\begin{array}{l}-0.246^{*} \\
(0.080)\end{array}$ & $\begin{array}{l}-0.077^{*} \\
(0.045)\end{array}$ & $\begin{array}{c}-0.405^{* * *} \\
(0.097)\end{array}$ & $\begin{array}{c}-0.311^{* * *} \\
(0.062)\end{array}$ & $\begin{array}{c}-0.339 * * * \\
(0.052)\end{array}$ \\
\hline Female & $\begin{array}{c}-0.258^{* * *} \\
(0.023)\end{array}$ & $\begin{array}{c}-0.301 * * * \\
(0.044)\end{array}$ & $\begin{array}{c}-0.269 * * * \\
(0.070)\end{array}$ & $\begin{array}{c}-0.223 * * * \\
(0.048)\end{array}$ & $\begin{array}{c}-0.300 * * * \\
(0.048)\end{array}$ \\
\hline Married & $\begin{array}{l}0.061^{*} \\
(0.025)\end{array}$ & $\begin{array}{c}0.112^{* *} \\
(0.046)\end{array}$ & $\begin{array}{c}0.092 \\
(0.094)\end{array}$ & $\begin{array}{c}0.036 \\
(0.059)\end{array}$ & $\begin{array}{c}0.001 \\
(0.062)\end{array}$ \\
\hline Urban & $\begin{array}{c}0.026 \\
(0.024)\end{array}$ & $\begin{array}{l}-0.036 \\
(0.041)\end{array}$ & $\begin{array}{l}0.128^{*} \\
(0.071)\end{array}$ & $\begin{array}{c}0.022 \\
(0.058)\end{array}$ & $\begin{array}{l}-0.017 \\
(0.046)\end{array}$ \\
\hline Secondary School & $\begin{array}{c}0.456^{* * *} \\
(0.057)\end{array}$ & $\begin{array}{c}0.335^{* * *} \\
(0.060)\end{array}$ & $\begin{array}{c}0.474^{* * *} \\
(0.114)\end{array}$ & $\begin{array}{c}0.534 * * * \\
(0.066)\end{array}$ & $\begin{array}{c}0.371^{* * *} \\
(0.101)\end{array}$ \\
\hline Tertiary & $\begin{array}{c}0.882 * * * \\
(0.105)\end{array}$ & $\begin{array}{c}0.761^{* * * *} \\
(0.073)\end{array}$ & $\begin{array}{c}0.926 * * * \\
(0.138)\end{array}$ & $\begin{array}{c}1.043^{* * * *} \\
(0.076)\end{array}$ & $\begin{array}{c}0.589 * * * \\
(0.114)\end{array}$ \\
\hline Number of Children & $\begin{array}{l}-0.024 \\
(0.014)\end{array}$ & $\begin{array}{l}-0.004 \\
(0.018)\end{array}$ & $\begin{array}{l}-0.013 \\
(0.030)\end{array}$ & $\begin{array}{c}-0.047 * * \\
(0.019)\end{array}$ & $\begin{array}{c}-0.073^{* *} \\
(0.034)\end{array}$ \\
\hline $\mathrm{N}$ & 3,887 & 1,343 & 711 & 1,257 & 576 \\
\hline
\end{tabular}


Table 6: Estimates for Labor Market Attachment among Adults

\begin{tabular}{|c|c|c|c|c|c|}
\hline & All & Bosnia & Croatia & Serbia & Montenegro \\
\hline & (1) & (2) & (3) & (4) & (5) \\
\hline & \multicolumn{5}{|c|}{ Panel A. Employment } \\
\hline Roma & $\begin{array}{c}-0.159 * * * \\
(0.021)\end{array}$ & $\begin{array}{c}-0.181^{* * *} \\
(0.022)\end{array}$ & $\begin{array}{c}-0.194 * * * \\
(0.042)\end{array}$ & $\begin{array}{c}-0.141^{* * *} \\
(0.024)\end{array}$ & $\begin{array}{c}-0.123^{* *} \\
(0.053)\end{array}$ \\
\hline Refugee \& IDPs & $\begin{array}{c}-0.140 * * * \\
(0.035)\end{array}$ & $\begin{array}{c}-0.055^{* * *} \\
(0.017)\end{array}$ & $\begin{array}{c}-0.161^{* * *} \\
(0.033)\end{array}$ & $\begin{array}{c}-0.193 * * * \\
(0.018)\end{array}$ & $\begin{array}{c}-0.192 * * * \\
(0.030)\end{array}$ \\
\hline Female & $\begin{array}{c}-0.175 * * * \\
(0.013)\end{array}$ & $\begin{array}{c}-0.141^{* * *} \\
(0.017)\end{array}$ & $\begin{array}{c}-0.165^{* * *} \\
(0.029)\end{array}$ & $\begin{array}{c}-0.176 * * * \\
(0.018)\end{array}$ & $\begin{array}{c}-0.255^{* * *} \\
(0.029)\end{array}$ \\
\hline Married & $\begin{array}{c}0.074 * * * \\
(0.016)\end{array}$ & $\begin{array}{c}0.069 * * * \\
(0.019)\end{array}$ & $\begin{array}{c}0.111^{* * *} \\
(0.035)\end{array}$ & $\begin{array}{c}0.079 * * * \\
(0.023)\end{array}$ & $\begin{array}{l}-0.005 \\
(0.038)\end{array}$ \\
\hline Urban & $\begin{array}{c}0.031 * * \\
(0.012)\end{array}$ & $\begin{array}{c}0.004 \\
(0.017)\end{array}$ & $\begin{array}{c}0.021 \\
(0.033)\end{array}$ & $\begin{array}{c}0.026 \\
(0.021)\end{array}$ & $\begin{array}{c}0.072 * * \\
(0.031)\end{array}$ \\
\hline Secondary School & $\begin{array}{c}0.247 * * * \\
(0.023)\end{array}$ & $\begin{array}{c}0.211^{* * *} \\
(0.023)\end{array}$ & $\begin{array}{c}0.255^{* * *} \\
(0.037)\end{array}$ & $\begin{array}{c}0.288 * * * \\
(0.025)\end{array}$ & $\begin{array}{c}0.225 * * * \\
(0.052)\end{array}$ \\
\hline Tertiary & $\begin{array}{c}0.424^{* * *} \\
(0.020)\end{array}$ & $\begin{array}{c}0.424^{* * *} \\
(0.039)\end{array}$ & $\begin{array}{c}0.384 * * * \\
(0.054)\end{array}$ & $\begin{array}{c}0.452 * * * \\
(0.035)\end{array}$ & $\begin{array}{c}0.415^{* * *} \\
(0.059)\end{array}$ \\
\hline \multirow[t]{2}{*}{ Number of Children } & $\begin{array}{c}-0.032 * * * \\
(0.009)\end{array}$ & $\begin{array}{l}-0.011 \\
(0.007)\end{array}$ & $\begin{array}{c}-0.045^{* * *} \\
(0.012)\end{array}$ & $\begin{array}{c}-0.047^{* * *} \\
(0.009)\end{array}$ & $\begin{array}{l}-0.014 \\
(0.012)\end{array}$ \\
\hline & \multicolumn{5}{|c|}{ Panel B.Unemployment } \\
\hline Roma & $\begin{array}{c}0.216 * * * \\
(0.041)\end{array}$ & $\begin{array}{c}0.338 * * * \\
(0.031)\end{array}$ & $\begin{array}{c}0.150 * * * \\
(0.046)\end{array}$ & $\begin{array}{c}0.204^{* * *} \\
(0.030)\end{array}$ & $\begin{array}{c}0.069 \\
(0.050)\end{array}$ \\
\hline Refugee \& IDPs & $\begin{array}{c}0.192 * * * \\
(0.049)\end{array}$ & $\begin{array}{c}0.099 * * * \\
(0.027)\end{array}$ & $\begin{array}{c}0.173^{* * *} \\
(0.040)\end{array}$ & $\begin{array}{c}0.262 * * * \\
(0.026)\end{array}$ & $\begin{array}{c}0.254^{* * *} \\
(0.033)\end{array}$ \\
\hline Female & $\begin{array}{c}-0.143 * * * \\
(0.013)\end{array}$ & $\begin{array}{c}-0.170 * * * \\
(0.021)\end{array}$ & $\begin{array}{c}-0.108^{* * *} \\
(0.028)\end{array}$ & $\begin{array}{c}-0.151^{* * *} \\
(0.020)\end{array}$ & $\begin{array}{c}-0.102 * * * \\
(0.027)\end{array}$ \\
\hline Married & $\begin{array}{c}-0.057 * * * \\
(0.014)\end{array}$ & $\begin{array}{l}-0.027 \\
(0.024)\end{array}$ & $\begin{array}{c}-0.096 * * \\
(0.038)\end{array}$ & $\begin{array}{c}-0.066 * * \\
(0.026)\end{array}$ & $\begin{array}{l}-0.060 * \\
(0.034)\end{array}$ \\
\hline Urban & $\begin{array}{c}0.027 \\
(0.038)\end{array}$ & $\begin{array}{c}0.118^{* * *} \\
(0.021)\end{array}$ & $\begin{array}{l}-0.015 \\
(0.033)\end{array}$ & $\begin{array}{c}0.023 \\
(0.023)\end{array}$ & $\begin{array}{c}-0.070 * * * \\
(0.027)\end{array}$ \\
\hline Secondary School & $\begin{array}{c}-0.095^{* *} \\
(0.042)\end{array}$ & $\begin{array}{l}-0.023 \\
(0.028)\end{array}$ & $\begin{array}{c}-0.137^{* * * *} \\
(0.036)\end{array}$ & $\begin{array}{c}-0.162 * * * \\
(0.024)\end{array}$ & $\begin{array}{c}-0.102 * * \\
(0.040)\end{array}$ \\
\hline Tertiary & $\begin{array}{c}-0.279 * * * \\
(0.012)\end{array}$ & $\begin{array}{c}-0.281^{* * *} \\
(0.032)\end{array}$ & $\begin{array}{c}-0.218^{* * *} \\
(0.042)\end{array}$ & $\begin{array}{c}-0.300 * * * \\
(0.024)\end{array}$ & $\begin{array}{c}-0.297^{* * *} \\
(0.029)\end{array}$ \\
\hline Number of Children & $\begin{array}{c}0.013 * * * \\
(0.005)\end{array}$ & $\begin{array}{c}0.001 \\
(0.007)\end{array}$ & $\begin{array}{c}0.034^{* * *} \\
(0.010)\end{array}$ & $\begin{array}{c}0.010 \\
(0.008)\end{array}$ & $\begin{array}{c}0.013 \\
(0.011)\end{array}$ \\
\hline $\mathrm{N}$ & 7,923 & 2,647 & 1,301 & 2,736 & 1,239 \\
\hline
\end{tabular}

Notes:The table reports marginal effect of Roma and R\&IDPs on employment and unemployment . Clustered standard errors by country are reported in parenthesis. Regressions control for schooling indicators; age and its square; a marriage, gender and urban dummies; Roma and R\&IDPs dummies; number of children and country fixed effects. ***1\%, ** 5\%, *10\% significance level. 


\begin{tabular}{|c|c|c|c|c|c|}
\hline & All & Bosnia & Croatia & Serbia & Montenegro \\
\hline & (1) & (2) & (3) & (4) & (5) \\
\hline Roma & $\begin{array}{c}0.307^{* * *} \\
(0.040)\end{array}$ & $\begin{array}{c}0.492^{* * *} \\
(0.060)\end{array}$ & $\begin{array}{c}0.022 \\
(0.063)\end{array}$ & $\begin{array}{c}0.281^{* * *} \\
(0.068)\end{array}$ & $\begin{array}{c}0.309 * * \\
(0.129)\end{array}$ \\
\hline Refugee \& IDPs & $\begin{array}{c}0.130 * * * \\
(0.040)\end{array}$ & $\begin{array}{c}0.161^{* *} \\
(0.069)\end{array}$ & $\begin{array}{l}-0.036 \\
(0.049)\end{array}$ & $\begin{array}{c}0.207 * * * \\
(0.061)\end{array}$ & $\begin{array}{c}0.055 \\
(0.102)\end{array}$ \\
\hline Female & $\begin{array}{c}-0.039 * * \\
(0.019)\end{array}$ & $\begin{array}{l}-0.018 \\
(0.036)\end{array}$ & $\begin{array}{l}-0.013 \\
(0.032)\end{array}$ & $\begin{array}{l}-0.027 \\
(0.032)\end{array}$ & $\begin{array}{c}-0.117^{* *} \\
(0.051)\end{array}$ \\
\hline Age & $\begin{array}{c}-0.048^{* * *} \\
(0.017)\end{array}$ & $\begin{array}{c}-0.087 * * * \\
(0.030)\end{array}$ & $\begin{array}{c}-0.058^{* *} \\
(0.027)\end{array}$ & $\begin{array}{l}-0.010 \\
(0.032)\end{array}$ & $\begin{array}{l}-0.007 \\
(0.052)\end{array}$ \\
\hline Age $^{2}$ & $\begin{array}{c}0.004^{* * *} \\
(0.001)\end{array}$ & $\begin{array}{c}0.005^{* * *} \\
(0.001)\end{array}$ & $\begin{array}{c}0.004^{* * *} \\
(0.001)\end{array}$ & $\begin{array}{c}0.003 * * \\
(0.001)\end{array}$ & $\begin{array}{c}0.002 \\
(0.002)\end{array}$ \\
\hline Household Head's Age & $\begin{array}{c}0.007 \\
(0.013)\end{array}$ & $\begin{array}{l}-0.002 \\
(0.021)\end{array}$ & $\begin{array}{c}0.026 \\
(0.026)\end{array}$ & $\begin{array}{c}0.003 \\
(0.026)\end{array}$ & $\begin{array}{l}-0.014 \\
(0.036)\end{array}$ \\
\hline Household Head's Age ${ }^{2}$ & $\begin{array}{l}-0.000 \\
(0.000)\end{array}$ & $\begin{array}{c}-0.000 \\
(0.000)\end{array}$ & $\begin{array}{l}-0.000 \\
(0.000)\end{array}$ & $\begin{array}{l}-0.000 \\
(0.000)\end{array}$ & $\begin{array}{c}0.000 \\
(0.000)\end{array}$ \\
\hline Household Heads years of schooling & $\begin{array}{c}-0.040^{* * *} \\
(0.004)\end{array}$ & $\begin{array}{c}-0.042 * * * \\
(0.006)\end{array}$ & $\begin{array}{c}-0.030 * * * \\
(0.007)\end{array}$ & $\begin{array}{c}-0.042 * * * \\
(0.007)\end{array}$ & $\begin{array}{c}-0.034 * * * \\
(0.011)\end{array}$ \\
\hline Household Heads Income & $\begin{array}{c}-0.034^{* *} \\
(0.015)\end{array}$ & $\begin{array}{c}0.028 \\
(0.028)\end{array}$ & $\begin{array}{c}-0.063^{* *} \\
(0.031)\end{array}$ & $\begin{array}{c}-0.049 * * * \\
(0.019)\end{array}$ & $\begin{array}{l}-0.044 \\
(0.051)\end{array}$ \\
\hline Observations & 2,998 & 1,130 & 493 & 973 & 402 \\
\hline
\end{tabular}




\begin{tabular}{|c|c|c|c|c|c|}
\hline & $\frac{\text { All }}{\text { (1) }}$ & $\frac{\text { Bosnia }}{(2)}$ & $\frac{\text { Croatia }}{(3)}$ & $\frac{\text { Serbia }}{(4)}$ & $\frac{\text { Montenegro }}{(5)}$ \\
\hline Roma & $\begin{array}{c}-1.679 * * * \\
(0.184)\end{array}$ & $\begin{array}{c}-2.239 * * * \\
(0.331)\end{array}$ & $\begin{array}{c}-0.783^{* *} \\
(0.325)\end{array}$ & $\begin{array}{c}-1.404^{* * *} \\
(0.287)\end{array}$ & $\begin{array}{c}-2.292 * * * \\
(0.693)\end{array}$ \\
\hline Refugee \& IDPs & $\begin{array}{c}-0.297 * * \\
(0.123)\end{array}$ & $\begin{array}{l}-0.084 \\
(0.195)\end{array}$ & $\begin{array}{l}-0.252 \\
(0.301)\end{array}$ & $\begin{array}{c}-0.496 * * \\
(0.205)\end{array}$ & $\begin{array}{l}-0.092 \\
(0.283)\end{array}$ \\
\hline Female & $\begin{array}{l}-0.018 \\
(0.086)\end{array}$ & $\begin{array}{l}-0.149 \\
(0.162)\end{array}$ & $\begin{array}{c}0.074 \\
(0.172)\end{array}$ & $\begin{array}{c}0.039 \\
(0.130)\end{array}$ & $\begin{array}{c}0.028 \\
(0.221)\end{array}$ \\
\hline Age & $\begin{array}{c}1.091^{* * *} \\
(0.076)\end{array}$ & $\begin{array}{c}1.130 * * * \\
(0.137)\end{array}$ & $\begin{array}{c}1.263 * * * \\
(0.142)\end{array}$ & $\begin{array}{c}1.116^{* * *} \\
(0.115)\end{array}$ & $\begin{array}{c}0.987 * * * \\
(0.238)\end{array}$ \\
\hline Age $^{2}$ & $\begin{array}{c}-0.017 * * * \\
(0.003)\end{array}$ & $\begin{array}{c}-0.021^{* * *} \\
(0.005)\end{array}$ & $\begin{array}{c}-0.023^{* * *} \\
(0.005)\end{array}$ & $\begin{array}{c}-0.016 * * * \\
(0.004)\end{array}$ & $\begin{array}{c}-0.011 \\
(0.008)\end{array}$ \\
\hline Household Head's Age & $\begin{array}{l}-0.108^{*} \\
(0.060)\end{array}$ & $\begin{array}{l}-0.078 \\
(0.103)\end{array}$ & $\begin{array}{l}-0.212 \\
(0.140)\end{array}$ & $\begin{array}{l}-0.052 \\
(0.130)\end{array}$ & $\begin{array}{l}-0.147 \\
(0.160)\end{array}$ \\
\hline Household Head's Age ${ }^{2}$ & $\begin{array}{l}0.001^{*} \\
(0.001)\end{array}$ & $\begin{array}{c}0.001 \\
(0.001)\end{array}$ & $\begin{array}{c}0.003 \\
(0.002)\end{array}$ & $\begin{array}{c}0.001 \\
(0.002)\end{array}$ & $\begin{array}{c}0.002 \\
(0.002)\end{array}$ \\
\hline Household Heads years of schooling & $\begin{array}{c}0.265^{* * *} \\
(0.020)\end{array}$ & $\begin{array}{c}0.259 * * * \\
(0.031)\end{array}$ & $\begin{array}{c}0.150 * * * \\
(0.043)\end{array}$ & $\begin{array}{c}0.259 * * * \\
(0.037)\end{array}$ & $\begin{array}{c}0.291 * * * \\
(0.066)\end{array}$ \\
\hline Household Heads Income & $\begin{array}{c}0.196 * * * \\
(0.069)\end{array}$ & $\begin{array}{c}0.028 \\
(0.139)\end{array}$ & $\begin{array}{c}0.343 * * \\
(0.163)\end{array}$ & $\begin{array}{c}0.188 * * \\
(0.084)\end{array}$ & $\begin{array}{l}0.424^{*} \\
(0.225)\end{array}$ \\
\hline Observations & 3,062 & 1,130 & 476 & 1,014 & 442 \\
\hline
\end{tabular}


Figure 1: Average Years of Schooling by Age groups

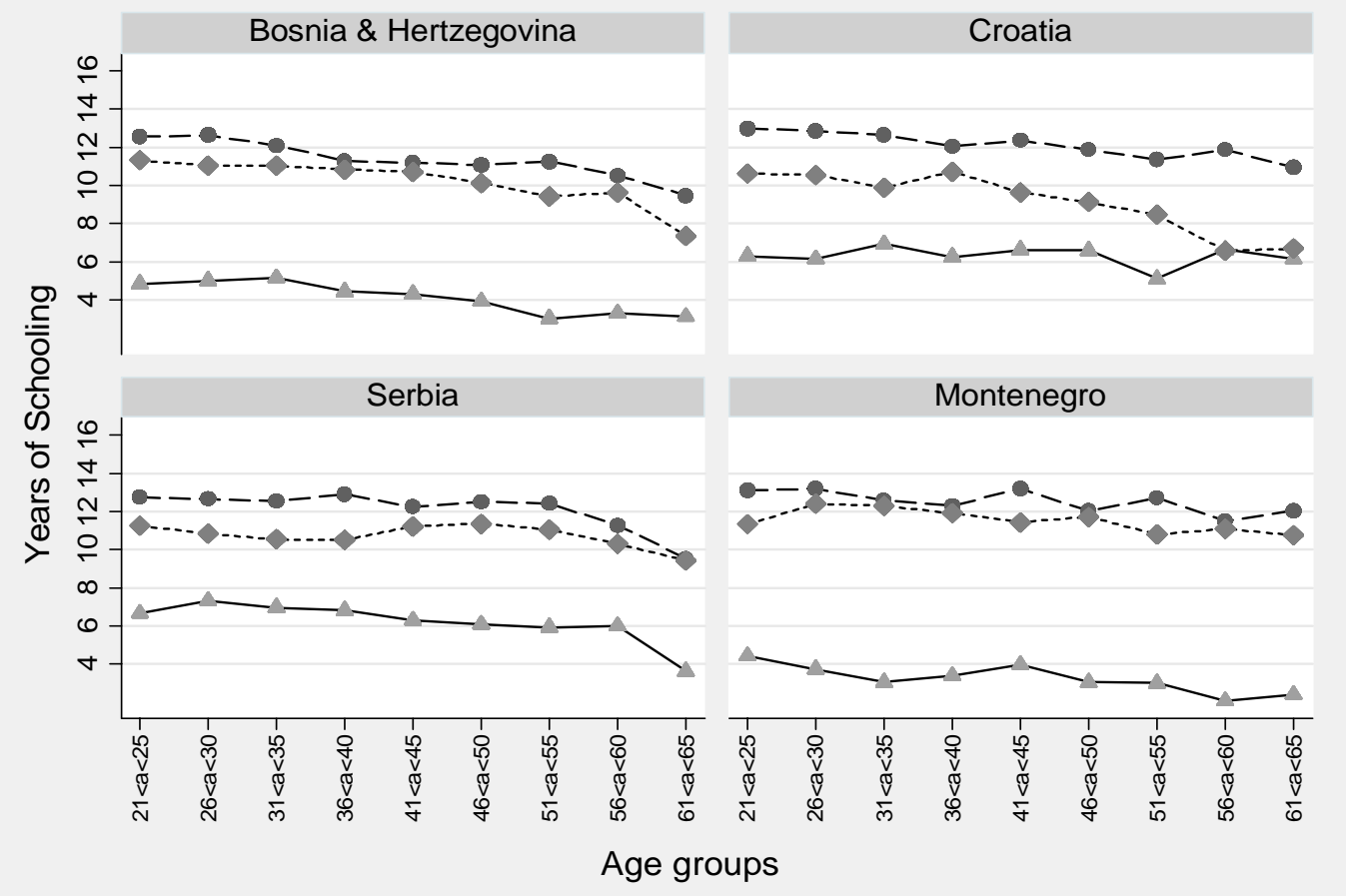

Notes: In figures, diamond presents the average for Roma, square the averages for RIDPs and circle the averages for majority population in the community. The averages by age groups are calculated using 2004 UNDP data set. 
Figure 2: Average Employment Probability by Age Groups

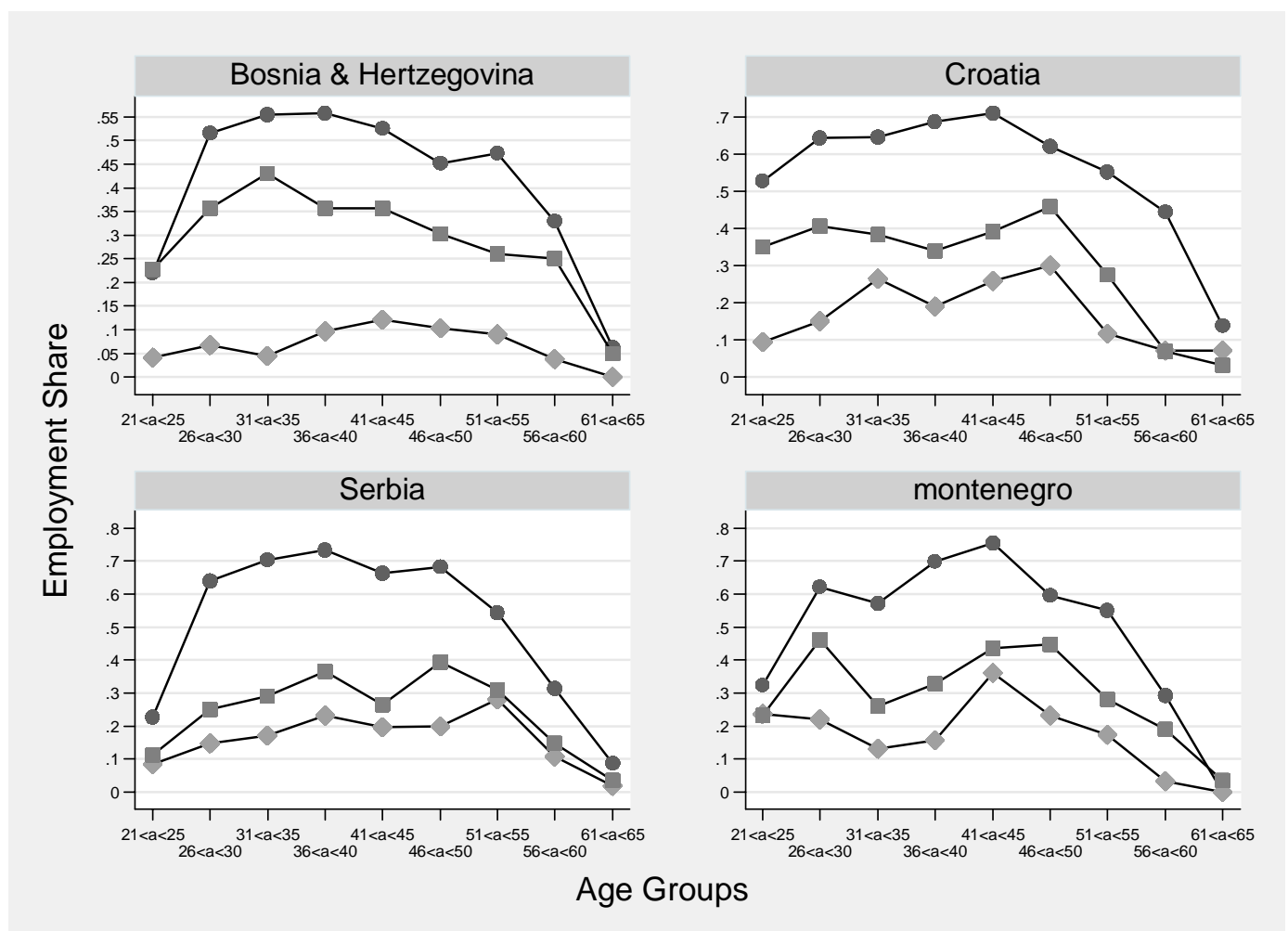

Notes: In figures, diamond presents the average for Roma, square the averages for RIDPs and circle the averages for majority population in the community. The averages by age groups are calculated using 2004 UNDP data set. 
Figure 3: Average Household Head's Income by Age Groups from All Sources

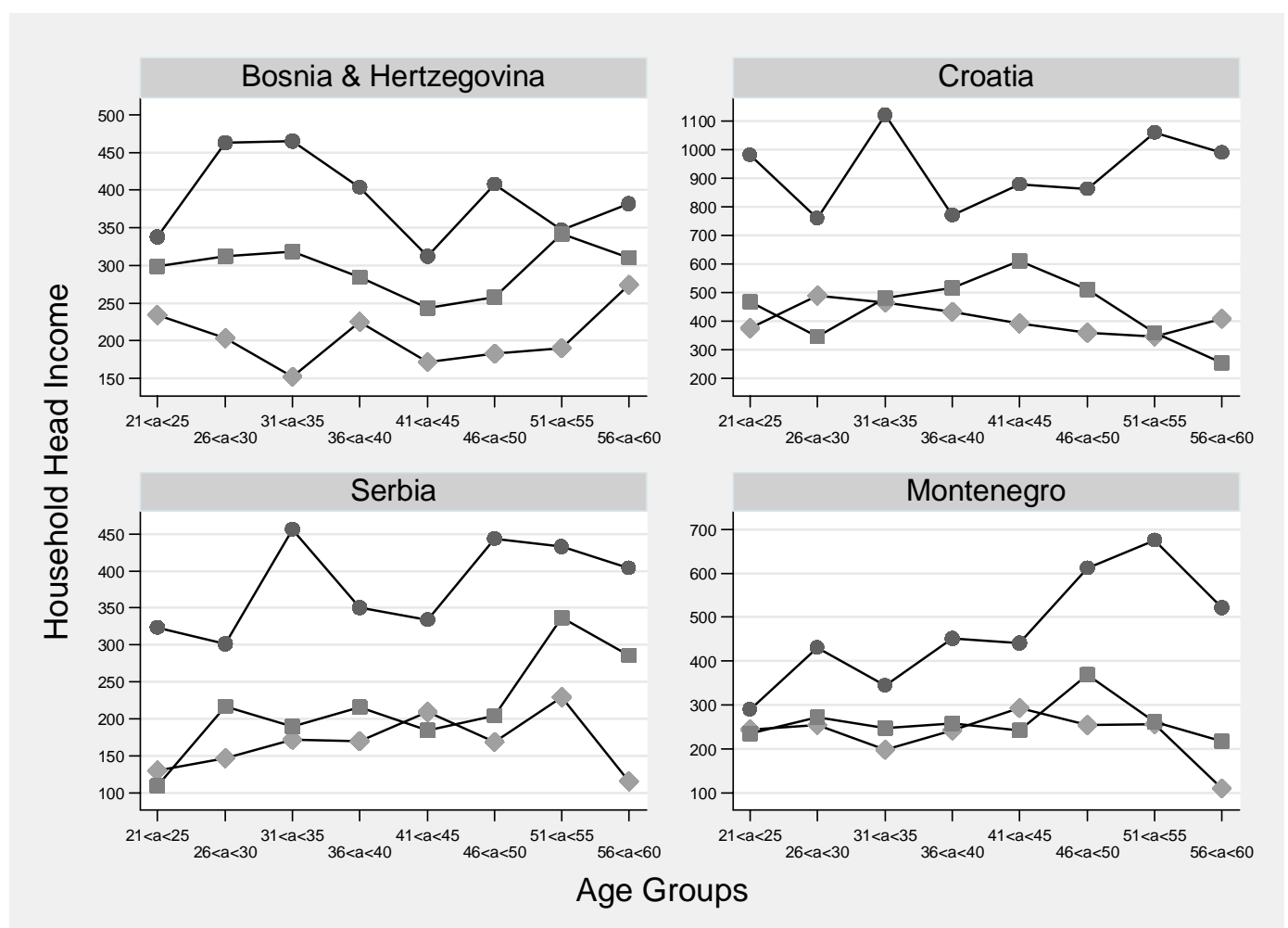

Notes: In figures, diamond presents the average for Roma, square the averages for RIDPs and circle the averages for majority population in the community. The averages by age groups are calculated using 2004 UNDP data set. 